\title{
Can postzygotic mutation in beta-actin be a common genetic etiology for Poland's syndrome and Becker's nevus syndrome?
}

\author{
Suresh Chandran ${ }^{1,2,3}$, Bin Huey Quek ${ }^{1,2,3}$, Eman Awadh Abduladheem Hashim ${ }^{4}$ \\ ${ }^{1}$ Department of Neonatology, KK Women's and Children's Hospital, Singapore, Singapore; ${ }^{2}$ Pediatric Academic Clinical Program, Lee Kong Chian \\ School of Medicine, Singapore, Singapore; ${ }^{3}$ Pediatric Academic Clinical Program, Duke NUS Medical School, National University of Singapore, \\ Singapore, Singapore; ${ }^{4}$ Department of Neonatology, Salmanya Medical Complex, Manama, Kingdom of Bahrain \\ Correspondence to: A/Prof. Suresh Chandran, Senior Consultant. Department of Neonatology, KK Women's and Children's Hospital, Singapore, \\ Singapore. Email: profschandran2019@gmail.com. \\ Response to: Cohen PR. Is there a genomic link and common pathogenesis (postzygotic mutations in beta-actin) for Poland syndrome and Becker \\ nevus syndrome? Transl Pediatr 2021. doi: 10.21037/tp-21-409.
}

Submitted Sep 09, 2021. Accepted for publication Sep 20, 2021.

doi: $10.21037 /$ tp-21-436

View this article at: https://dx.doi.org/10.21037/tp-21-436

We thank Dr. Cohen for his comments on our narrative review on Poland's syndrome published in Translational Pediatrics (1).

Poland's syndrome is characterized by hypoplasia or aplasia of pectoral muscles, mammary hypoplasia, variably associated ipsilateral limb anomalies, rib deformities and dextrocardia (1). Becker's nevus syndrome is a genodermatosis characterized by a unilateral tan patch in childhood to cutaneous hamartoma (Becker's nevus), typically with circumscribed hyperpigmented tissue and hypertrichosis on their torso or upper extremities in adolescence and some with associated ipsilateral hypoplasia of the breast, pectoral muscles, and other musculoskeletal anomalies, developmental delay, mental retardation and cardiomyopathy (2). Musculoskeletal anomalies seen in Poland's syndrome are indistinguishable from that in Becker's nevus syndrome, even though dermatological manifestations are less often reported in Poland's syndrome, which includes anhidrosis, ipsilateral axillary and pectoral alopecia, cutaneous hemangioma and congenital melanocytic nevus (1). Vascular disruption sequence affecting the subclavian artery and its branches remains the most accepted theory for the genesis of Poland's syndrome (3).

Researchers have noticed significant phenotypic similarities between Becker's nevus syndrome and Poland's syndrome. We authors noted Cai et al.'s observation of the clinical findings in Becker's nevus syndrome, having unilateral breast and pectoral muscle hypoplasia, very much resembling Poland's syndrome. They provided evidence that Becker's nevus syndrome is caused by a lethal mutation in the $A C T B$ gene, which codes for beta-actin. Cai et al. hypothesized that the $A C T B$ mutations intensify hedgehog signaling, resulting in hair growth abnormalities and pilar muscle development (4).

Poland's syndrome has been linked to several gene mutations, but none were consistently associated with its clinical features (1). Beta-actin mRNA plays a crucial role in cell migration and differentiation during embryogenesis (5); potentially, this mutation may interfere with vascular growth and differentiation, causing disruption resulting in Poland's syndrome.

We support research into Cohen's proposal of a common etiology, postzygotic mutations in beta-actin, for both syndromes in the background of identical phenotypic features (6). Genetic studies of patients with Poland's syndrome may uncover its potential relationship with Becker's nevus syndrome.

\section{Acknowledgments}

Funding: None.

\section{Footnote}

Provenance and Peer Review: This article was commissioned 
by the Editorial Office, Translational Pediatrics. The article did not undergo external peer review.

Conflicts of Interest: All authors have completed the ICMJE uniform disclosure form (available at https://dx.doi. org/10.21037/tp-21-436). The authors have no conflicts of interest to declare.

Ethical Statement: The authors are accountable for all aspects of the work in ensuring that questions related to the accuracy or integrity of any part of the work are appropriately investigated and resolved.

Open Access Statement: This is an Open Access article distributed in accordance with the Creative Commons Attribution-NonCommercial-NoDerivs 4.0 International License (CC BY-NC-ND 4.0), which permits the noncommercial replication and distribution of the article with the strict proviso that no changes or edits are made and the original work is properly cited (including links to both the formal publication through the relevant DOI and the license). See: https://creativecommons.org/licenses/by-nc-nd/4.0/.

Cite this article as: Chandran S, Quek BH, Hashim EAA. Can postzygotic mutation in beta-actin be a common genetic etiology for Poland's syndrome and Becker's nevus syndrome? Transl Pediatr 2021;10(10):2641-2642. doi: 10.21037/tp-21-436

\section{References}

1. Hashim EAA, Quek BH, Chandran S. A narrative review of Poland's syndrome: theories of its genesis, evolution and its diagnosis and treatment. Transl Pediatr 2021;10:1008-19.

2. Torchia D. Becker nevus syndrome: A 2020 update. J Am Acad Dermatol 2021;85:e101-3.

3. Bavinck JN, Weaver DD. Subclavian artery supply disruption sequence: hypothesis of a vascular etiology for Poland, Klippel-Feil, and Möbius anomalies. Am J Med Genet 1986;23:903-18.

4. Cai ED, Sun BK, Chiang A, et al. Postzygotic Mutations in Beta-Actin Are Associated with Becker's Nevus and Becker's Nevus Syndrome. J Invest Dermatol 2017;137:1795-8.

5. Happle R. Becker's Nevus and Lethal Beta-Actin Mutations. J Invest Dermatol 2017;137:1619-21.

6. Cohen PR. Poland's Syndrome: Are Postzygotic Mutations in $\beta$-Actin Associated with its Pathogenesis? Am J Clin Dermatol 2018;19:133-4. 